\title{
The Time of My Life: The Marketing Lessons from "Dirty Dancing"
}

\author{
Michael L. Omansky \\ Associate Professor, Business Division, \\ Felician College, 223 Montross Avenue, \\ Rutherford, NJ 07070
}

\begin{abstract}
"Dirty Dancing" was a movie with a major soundtrack. The soundtrack had a coordinated marketing effort, took on a life of its own but continued to succeed with guidance and control for over a decade. Its success contains many marketing lessons that can be applied to other projects.
\end{abstract}

Key Words: Promotion, Radio, Retail, Soundtrack, Collaboration

\section{INTRODUCTION}

On August 21, 1987, I was in a movie theater on the upper east side of New York City. This was the official premiere of a movie, "Dirty Dancing".

While the film had been first shown at the 1987 Cannes Film Festival three months prior, this was really the big evening. As VP Marketing at RCA Records in NY, my company had a major interest in the project. We had the soundtrack and were looking to the response from critics and the public. I had seen a "rough cut" of the film the prior winter, along with others from RCA Records, the motion picture company Vestron, and the guiding hand behind the project, Jimmy Ienner. Jimmy Ienner oversaw the music, which was an integral part of the movie's experience; but was also integrally involved with every step of the movie, the author Eleanor Bergstein, and guiding both Vestron and RCA Records.

On that night in August, in a theater with movie executives, record company executives, and the press, there was a standing ovation at the end of the film. While hardly a scientific poll, I knew we had something...the question was how big it could be. However, we had not waited for that night to set up the record album. Win, lose, or draw, we were ready from a consumer marketing standpoint, and were about to go on a very positive, wild ride.

The President of RCA Records, Bob Buziak, had signed the record deal bringing us "Dirty Dancing", and the Executive Vice President, Rick Dobbis, was going to stay on top of the organization to maximize the success. In the months prior to the premiere, Alan Grunblatt, Product Director for the project and I had met with a large group of people at Vestron. Vestron and RCA Records worked on promotions to generate consumer awareness of the film. On the day the film opened, we had set up "Dirty Dancing" contests at theme parks across the country; had contests in a number of teen 
magazines; contests in shopping malls with stores geared to female teens; and a major publicity effort.

At RCA Records, we faced a tricky problem. Most soundtrack albums were not successful. We wanted music albums (vinyl, CDs and cassettes at that time) in music chains and the mass merchants. However, with no track record, retail outlets were reluctant to take product in. Alan and I worked with our VP Sales, Dave Wheeler, and Pete Jones, the President of BMG Distribution (our distribution company) *, to come up with a plan - account by account, chain by chain - to get albums into stores for the film opening. This was not an easy task, but doable with coop advertising money (i.e. money for the retailers to run local advertising), discounting, and "dating" (dating means giving retailers a longer time to pay for their orders). It was a major effort by the two sales forces involved, and we met our objective of putting 200,000 albums spread out in the market, across the country. This way, if someone saw the movie, they could go buy the soundtrack.

Publicity was terrific. The marketing efforts were strong. The movie was a hit. Word of mouth made it \#1 at the box office in the U.S. Stores quickly sold out of the album. The 200,000 copies that took such an effort to get into the marketplace would soon look like a rounding error. That Monday RCA Records had orders from the retail universe for another 1 million copies, and orders for another million came in by the end of the week. Jimmy Ienner was busy talking to people across RCA Records and BMG Distribution, at all levels, staying on top of every move.

Meanwhile, albums were flying off the shelf, without the usual most important success component for a record company: a song being played on radio. We released the first single, "(I had) The Time of My Life" - the biggest song in the film -- and radio initially didn't want to play it. The feedback varied, but it wasn't seen as a hit. In addition, we had created a music video for the song, and the primary video outlet, MTV, wanted to know where the radio airplay was before they aired it. For the next two weeks, radio wouldn't play the record, albums flew out of stores, and MTV was still holding out. We serviced the video to night clubs across the country, and it was reportedly receiving a great response.

Finally, one station took a chance; the song went overnight to \#1 in the market (meaning the single was selling that strongly at retail), and the song spread almost instantly across the country at the rest of radio. MTV started playing the video. Thus, by the end of September, radio found that it had a "hit".

For 18 weeks, "Dirty Dancing" would be the \#1 album on the Billboard Album chart in the United States. Similarly, the success expanded around the world, particularly in Europe.Research showed that young females were seeing the movie, in theaters, multiple times. Now we had a new mission. How high was up? The mission was now to continue the success; maximize sales; and keep "Dirty Dancing" top of mind. We didn't know at the time, but this would keep going strong, in different ways, for the next 15 years.

With a \#1 movie and \#1 album, Vestron's video division was now looking to release the video initially on VHS (the format at the time) - for rental stores. In those days, the video has a high retail price (around \$69.98), so it was geared to Blockbuster, Hollywood Video, mom and pop video 
rental stores - not really for purchase by consumers. Once the rental market was saturated, the price would be lowered after about six months, to launch into consumer outlets for purchase.

Alan Grunblatt and I returned to Vestron and met with the video division. Their mission was to convince distributors to order many copies, and distributors would in turn sell to video stores. Their concern was having something that looked like a consumer marketing plan, so distributors would see that there would be support. I suggested that we pool financial resources and promote both the album and the video release simultaneously. We came up with a real consumer marketing plan encompassing TV and print advertising. The one thing that I requested in all of this - and got - was an advertisement for the album at the front of the video. To me, this was the most important component for us: in six months, there would be 50 million potential exposures of my ad.

We went back again when the video arm was moving to the lower-priced consumer market, and again pooled resources to push both projects. Consumers who purchased the VHS apparently viewed the movie over and over. In the days of VHS, research showed that consumers - again young females in particular - rebought the video when the tape from their original copy broke.

Meanwhile, there was a balancing act producing the right quantities of each configuration, and not going out of stock. I had recruited a production expert, Lou Vaccarelli from Sony, who for the next year would be having various factories produce "Dirty Dancing" to keep up with demand. He was always asked "don't produce too much, but never run out". Fortunately, he was great at the balancing act.

The marketing was on-going. We paid money for local advertising, to keep the album positioned (visible/on display) at retail. We did TV campaigns on MTV, and in the mainstream. We did radio promotions on major stations, with substantial prizes for contest winners. We continued to spend money into the success. Key: if you stop spending too soon, you lose sales. If you overspend, you kill your profits. This ended up as a very profitable success, fueled by substantial sales.

By the following December, those of us who worked on the project received a plaque, certified by the Recording Industry Association of America, for 10 million copies sold in the United States (10 times platinum, which itself is 1 million).

Also, during the second year, we launched a second album, "More Dirty Dancing". These were, of course, songs that didn't make the first album. At the time, a major industry researcher, Mike Shalett, and I had done a marketing research study, to determine the potential of the second album. It came back as 3 million albums to be sold in the first year. When I excitedly brought this information to a marketing meeting, one of the other executives said, "From your lips to God's ears". As it turned out, we did over 3 million copies in the first year. It also gave us an opportunity to merchandise both albums together at retail and sell even more of each.

I left my job as VP at RCA Records in 1990 to work on a different opportunity, still connected with the company. After my departure, there was major personnel "sea change", that lasted for three years; then there would be another "sea change". The new regime approached me on returning to the company to build and run a global profit center, which I did. On the first morning, of my first day, in October 1995, I called Jimmy Ienner. He knew of my return and knew what was on my mind. We were approaching the $10^{\text {th }}$ anniversary of "Dirty Dancing". The album was still selling 
month after month, year after year, but now we had an opportunity to make it a major effort once more. We met and brainstormed the approach that we would ultimately take.

The driving concept was "Dirty Dancing: The Collector's Edition”. We were now in the world of compact discs only, and this would be a 2CD set of the albums, sold as one unit. However, to make it truly special for fans, we came up with the idea of a special booklet, with photos never before published, from the original movie shoot. Jimmy knew where such photos could be found - at the home of the author of "Dirty Dancing", Eleanor Bergstein. We spent an afternoon with her, reviewing many terrific photos that she had taken. We put these in the hands of Jimmy Ienner Jr., who had a creative services agency and was incredible with photo collections, who created our booklet. Along the way, we got the required legal permission to use the photos with the album.

By now, the original movie company, Vestron, was no more, and the movie and video rights had been acquired by Live Video, in California. I reached out to the President of Marketing and Sales at the company, and we met for an hour in New York about what might be done between the two companies. I outlined my plans for the launch of Collector's Edition. He loved it and decided to launch a collector's edition of the DVD and have the exact same date of release as my album. We then put together a plan to have the sales forces from each company work together, call on major accounts, and ultimately display both the DVD and audio products together at retail. Both companies had successful launches. I went on QVC, just before the album was released, for a "presell”, to help generate awareness prior to general retail availability. In addition, we put together a TV campaign, targeted to adult females, on daytime shows, to generate awareness.

Meanwhile, we looked to the rest of the world. We would have a simultaneous global launch of the new project, but also wanted to sell more copies of the original two albums along the way. There were two key people in Germany who helped me corral the rest of the world -- Klaus Schmalenbach, a brilliant strategist who could bring about practical success; and Wolfgang Eckart, a talented coworker. They had suggested a "one day sale" of the original album across Europe. Simply, lower the price to retailers for one day - they could buy whatever they wanted - an determine how much of a discount would be given to consumers at retail. This was an instant success: the one day brought about sales of 1 million copies overseas. We repeated it six months later - again, over 1 million copies. For the next four years, we periodically would run one-day sales, with similar results.

“Dirty Dancing: The Collector's Edition”, was a successful project in both the U.S., and globally. Over 40 million copies of the original album have been sold. After my tenure, there was a "20 th Anniversary Edition" as well.

The "Dirty Dancing" album success obviously needed the consumer acceptance. However, it was a massive, coordinated effort of all of the areas of RCA Records - radio promotion; publicity; video promotion; production; creative services; product management; business affairs (law); the leadership (President Buziak and EVP Dobbis); the distribution company headed by Pete Jones; sales; and the guiding hand of Jimmy Ienner. This was an amazing collaboration. 
However, there are key lessons from all of this:

1. A successful marketing effort is all inclusive. While it requires leadership and vision, it happens with the ideas and efforts of people who know their craft.

2. Planning reaps rewards. If we didn't put 200,000 albums in stores up front, and have major efforts across the country, we would not have been ready for the organic success that followed. The fact that we had consumer promotions and advertising out the day the movie hit, paid off.

3. Know when and how to spend, to maximize sales on a project.

4. Use all the appropriate resources, whether they are internal (promotions; ad budgets), or external (partnering on segments of the project first with Vestron, then ten years later with Live Entertainment).

5. Keep your eyes on the consumer. "Dirty Dancing: The Collector's Edition" - at year 10 - was designed and presented to the market with the fan base in mind.

6. Ride the tails of the success - the European "one day sales" sold millions of extra copies of the original album, as a sidebar to the new product.

7. Magic, when it exists, helps. We had that with Jimmy Ienner, the original visionary of the project.

8. Don't give up early. Radio originally signaled that "(I had) Time of My Life" was not worth air play. It went on to be \#1 single in the U.S., as well as \#1 in Australia, Belgium, Canada, Netherlands, and South Africa.

In the U.S., the marketplace was telling us that consumers embraced the project...radio had to catch up.

1. Most important, don't end a project early - always ask "what can we do next?". The movie had been out for ten years, when an additional product and renewed marketing effort put new zest - and sales - into the project.

"Dirty Dancing" is generally recognized as the fifth best-selling soundtrack of all time. It touched people's lives. It started with teenage girls; moved on to be a mother-daughter album; and in 2020 is a grandmother-mother-daughter shared experience.

\section{References}

Browne, D. (2017). The 'Dirty Dancing' Soundtrack: 10 Things You Didn't Know. Retrieved from https://www.rollingstone.com/music/music-news/the-dirty-dancing-soundtrack-10-things-youdidnt-know-203885/

Eleanor Bergstein biography. (2020). Retrieved

from https://www.imdb.com/name/nm0075044/bio?ref_=nm_ov_bio_sm ${ }^{\sqrt{ }}$

Popson, T. (1989, May 19). 'Dirty Dancing' gets four stars from the Contours. Chicago Tribune, p. 50.

Wierl, M. (2019). 'Dirty Dancing': 10 Facts about the Iconic Soundtrack. Retrieved from https://www.promipool.com/retro/dirty-dancing-10-facts-about-the-iconic-soundtrack

Yates, H. (2019). How we made 'Dirty Dancing's (I've Had) the Time of my Life. Retrieved from https:/www.theguardian.com/music/2019/apr/09/how-we-made-dirty-dancing-ive-had-the-timeof-my-life. 